\title{
Biocompatibility of propolis in subcutaneous tissue of rats: a possible biomaterial for cavity cleansing
}

Mailza Costa de Almeida ${ }^{a}$, Luiz Carlos de Lima Ferreira ${ }^{b}$, Gisely Naura Venâncio ${ }^{a}$, Risonilce Fernandes Silva de Souzac, Emerson Silva Lima ${ }^{d}$, Nikeila Chacon de Oliveira Conde ${ }^{a}$, Maria Fulgência Costa Lima Bandeira ${ }^{a}$

\begin{abstract}
OBJECTIVE: The aim of this study was to histopathologically analyze, in subcutaneous connective tissue in rats, a propolis solution for cavity cleansing and its toxicity through hemolytic and Artemia franciscana tests.

METHODS: Fifteen male rats were selected and randomly distributed in three experimental periods (07, 30 and 45 days), in which each animal received the four treatment groups in rounds: Group I Propolis I; Group II - Propolis II; Group III - Calcium Hydroxide Water and Group IV - 2\% Chlorexidine; the sides of the tube were the control group. The data were analyzed using descriptive statistics. The results showed, in terms of biocompatibility, that all materials presented a significant reduction of the inflammatory infiltrate and an increase of the thickness in the collagen fibers. It may be suggested, in decreasing order of biocompatibility, the use of following materials: calcium hydroxide-water, $2 \%$ chlorexidine, propolis I and propolis II.

RESULTS: In the cytotoxicity test using $A$. franciscana, the propolis extract showed high toxicity when tested at concentrations and in the hemolytic activity test the propolis I extract showed greater activity than propolis II.

CONCLUSION: The present study suggests the use of propolis as a cavity cleansing solution for shallow and medium cavities similar to $2 \%$ chlorexidine.
\end{abstract}

Key words: Materials testing; Propolis; Dental cavity lining; Detergents

\section{Biocompatibilidade da própolis no tecido subcutâneo de ratos: um possível biomaterial de limpeza de cavidade}

\section{RESUMO}

OBJETIVO: O objetivo deste estudo foi analisar histopatologicamente, em tecido conjuntivo subcutâneo de ratos, uma solução de própolis para a limpeza de cavidades e sua toxicidade através dos testes de hemólise e Artemia franciscana.

METODOLOGIA: Foram utilizados 15 ratos machos, selecionados e distribuídos aleatoriamente em três grupos $(n=5)$ em períodos experimentais (7, 30 e 45 dias), em que cada animal recebeu os quatro grupos de tratamento em forma de rodízio: Grupo I - Própolis I; Grupo II - Própolis II; Grupo III - Água de Hidróxido de Cálcio e Grupo IV - Clorexidina a 2\%; as laterais do tubo foram o grupo controle. Os dados foram analisados pela estatística descritiva.

RESULTADOS: Todos os materiais apresentaram uma redução significativa do infiltrado inflamatório e aumento da espessura das fibras colágenas. No teste de citotoxicidade de Artemia franciscana, o extrato de própolis apresentou alta toxicidade e no teste de atividade hemolítica o extrato de Própolis I mostrou-se mais ativo que o da Própolis II.

CONCLUSÃO: O presente estudo mostrou a biocompatibilidade da própolis, sugerindo seu uso como solução de limpeza em cavidade cavidades rasas e médias semelhante à clorexidina a $2 \%$.

Palavras-chave: Teste de materiais; Própolis; Forramento da cavidade dentária; Detergentes

\author{
a Department of Post-Graduation, School of \\ Dentistry, Federal University of Amazonas, Manaus, \\ Brazil \\ ${ }^{\mathrm{b}}$ Department of Pathology and Legal Medicine, \\ School of Medicine, Federal University of Amazonas, \\ Manaus, Brazil \\ ${ }^{c}$ Department of Research in Health Science, \\ National Research Institute of Amazonas, Manaus, \\ Brazil \\ ${ }^{d}$ Department of Clinical Analysis, School of \\ Pharmaceutical Sciences, Federal University of \\ Amazonas, Manaus, Brazil
}

Palavras-chave: Teste de materiais; Própolis; Forramento da cavidade dentária; Detergentes

A




\section{INTRODUCTION}

The general principles of cavity preparation were altered because of the bond restorative materials to tooth structure. Carious dentin must be removed until a leathery consistency layer of dentin is reached promoting a successful and long-term survival of the restoration [1]. Whenever there is an abrasion or cut in the dental structure, a surface called smear-layer is formed, comprised of organic and inorganic materials, blood, saliva, oils from rotatory instruments, microorganisms and their products [2].

The cavity cleansing aims to effectively remove most of the residues that can harm adaptation, marginal sealing and at the same time reduce the amount of microorganisms and their products [3].

Propolis is a complex mix of resinous, gummy and balmy substances gathered by Apis mellifera bees from sprouts, flowers and plant exudates, in which the bees add salivary secretions, wax and pollen to generate the final product [4]. It has a bactericide, antimicrobial [5], antioxidant [6], antifungal [7], healing, anti-inflammatory [8], anti-cancerous, anti-HIV [9] and anti-carious biological function [10].

The propolis components vary according to the collection location and the vegetal species used by the bees in its production process. Chemically, propolis presents 160 components. Among the identified compounds, we can note flavonoids (flavones, flavolones, flavonones), chalcones, benzoic acid and derivates, benzaldeids, alcohols, acetones, fenolics, heteroaromatics, cinnamic alcohol and derivates, diterpen and triterpen acids, minerals and other elements [6].

In order to enable the clinical use of this new biomaterial, extensive research is needed, including evaluating the biological compatibility of the product, to prove its safety and to enable its use in dentistry. The toxicity of a dental material can be evaluated by in vitro tests in animals and humans. When a new product is developed, it is necessary to perform laboratorial tests with it, allowing safe clinical applications, and providing subsides for its use by health professionals and clinics proving its non-toxicity to tissue $[11,12]$.

The purposes of this study were to analyze the biocompatibility of a propolis solution cavity cleansing in rat subcutaneous connective tissue and the toxicity through hemolytic and Artemia franciscana tests.

\section{METHODS}

The propolis (Appis melifera) samples were collected in two apiaries in the State of Amazonas, Brazil, in four different beehives using the scraping method. The samples were obtaine with $8 \%$ ethanolic extract following guidelines directions of the Brazilian Pharmacopeia for an appropriate cavity cleansing solution [13].

This research was approved by the Animal Research Ethics Committee of the Federal University of Amazon (55/2011). Fifteen male young adults Rattus norvegicus rats,
Rodentia mammalian, Wistar lineage were used, weighing on average 180 to 220 grams [14].

For the surgical procedure, the animals were anesthetized with ketamine hydrochloride $10 \%, 0,15 \mathrm{~mL} / 100 \mathrm{mg}$ (Ketamine ${ }^{\circledR}$, Syntec, São Paulo, Brazil), and muscle relaxant (Rompum $^{\circledR}$, Xylaxine hydrochloride $2 \%, 0.01 \mathrm{~mL} / 100 \mathrm{mg}$ - Bayer from Brazil S/A, São Paulo, Brazil), followed by anti-sepsis with iodated alcohol and trichotomy of the dorsal area. At the mean line, two incisions were made, one pelvic and the other scapular, of approximately 1 centimeter in length, followed by divulsion.

Polyethylene tubes were implanted on rounds in each side of the animal and kept parallel to the incision, and each animal $(\mathrm{N}=15)$ received the four experimental groups. The test groups were denominated Group I: propolis I (PI); Group II: propolis II (PII); Group III: Calcium Hydroxide Water (CHW); Group IV: 2\% Chlorexidine ${ }^{\circledR}(\mathrm{CH})$ (FGM, Joinville, Santa Catarina, Brazil). The test specimens were retained in situ for experimental periods of 7, 30 and 45 days $(n=5)$.

To begin the study, the animals were observed until full recovery. Later, they were put in cages, taken to a mouse facility and fed a balanced diet and water ad libitum. After the experimental periods, the rats were once again anesthetized and, after locating the tubes, the tissue fragments that contained them were removed with a wide safety margin, and then immersed in $10 \%$ buffered neutral formalin and sent for histopathologic processing with $6 \mu \mathrm{m}$-wide cuts and then dyed with Hematoxylin and Eosin [14]. The animals were anesthetized and sacrificed.

Histopathologic analysis was performed with a microscope and the following cellular elements were considered for evaluation of the analysis: presence of inflammatory cells, neutrophils, eosinophils, lymphocytes, macrophages and giant cells, deposits of collagen fibers and abscess formation. The cellular events were classified according to scores (Table 1).

Table 1. Scores according to the intensity of the inflammatory process

\begin{tabular}{ccl} 
Score & $\begin{array}{c}\text { Intensity of the } \\
\text { inflammatory process }\end{array}$ & \multicolumn{1}{c}{ Description } \\
\hline 1 & Absent & $\begin{array}{l}\text { no inflammatory cells } \\
\text { presence of inflammatory cells } \\
\text { very sparsely or in small groups } \\
\text { presence of inflammatory cells in } \\
\text { groups, but not dominating the } \\
\text { microscopic field } \\
\text { presence of inflammatory cells } \\
\text { dominating the microscopic field } \\
\text { and near the tested material }\end{array}$ \\
\hline 4 & Moderate & Intense \\
\hline
\end{tabular}

The fibrous formation was classified according to estabilished scores [15] (Table 2).

The abscess, characterized by the presence of degenerated neutrophils (piocites) in an area of the microscopy field, was also classified according to scores [15] (Table 3). 
Table 2. Scores according to the intensity fibrous formation

\begin{tabular}{cl}
\hline Score & \multicolumn{1}{c}{ Description } \\
1 & $\begin{array}{l}\text { Absence of collagen fiber deposits involving the area } \\
\text { containing the studied material }\end{array}$ \\
2 & $\begin{array}{l}\text { Presence of deposits of a fine layer of collagen fibers } \\
\text { involving the studied material }\end{array}$ \\
3 & $\begin{array}{l}\text { Presence of a thick layer of collagen fiber involving the } \\
\text { studied material }\end{array}$ \\
\hline
\end{tabular}

Table 3. Scores according to the presence and area of abscess

\begin{tabular}{|c|c|}
\hline Score & Description \\
\hline 1 & Absence of abscess \\
\hline 2 & $\begin{array}{l}\text { Presence of abscess related to the place containing the } \\
\text { tested material }\end{array}$ \\
\hline 3 & $\begin{array}{l}\text { Presence of abscess reaching areas farther from the place } \\
\text { containing the tested material }\end{array}$ \\
\hline
\end{tabular}

A study of the toxicity of the extracts was performed using Artemia franciscana (A. franciscana) as a model. The $A$. franciscana cysts were cultured in a Petri dish $(90 \mathrm{~mm} \times 15 \mathrm{~mm})$ containing a $3.5 \%$ saline solution, for 48 hours at room temperature under continuous luminosity. After 48 hours, the eggs hatched and the larvae were ready for testing. After the hatching period, $1.800 \mathrm{~mL}$ of the $3.5 \%$ saline solution were added to a microplate $(4 \times 6)$, and in those wells were inserted $10 \mathrm{~A}$. franciscana nauplii, and then $20 \mathrm{~mL}$ of the $8 \%$ propolis ethanolic extract, incubated for 24 hours at room temperature in the dark. This procedure was performed three times. The negative control followed the same procedure, but using $20 \mathrm{~mL}$ of dimethsulfoxide without adding the extract [16]. The mortality rate was determined in \% mortality $=$ (number of dead individuals $\times$ 100) / total number of individuals, and the degree of toxicity was classified according to the mortality observed: $0-9 \%=$ non-toxic (NT); $10-49=$ slightly toxic $(\mathrm{ST}) ; 50-89 \%=$ toxic (T); $90-100 \%=$ highly toxic (HT) [17].

For the hemolytic test, venous blood was collected first in EDTA and then it was processed at $2500 \mathrm{rpm}$ for 10 minutes. The supernatant was ignored and the infranatant was collected. A total of $1 \mathrm{~mL}$ of the infranatant (red blood cells) in $99 \mathrm{~mL}$ of a phosphate buffer with $\mathrm{pH} 7$ forming the red blood cell solution. The experimental groups were: Group I - P I; Group II - P II; Group III - Triton X-100 Solution (control) and Group IV - 80\% Ethanol (white). The tubes were made homogeneous and incubated at $37^{\circ} \mathrm{C}$ for 5 minutes. After this period, they were processed at 3000 rpm for 5 minutes. The readings were performed in the microplate reader at $540 \mathrm{~nm}$. The hemolysis of the sample was calculated by the formula:

$$
\% \text { hemolysis }=100-\frac{\text { Absorbance test }}{\text { Absorbance control } 100 \%} \times 100
$$

The data were tabulated and analyzed through descriptive statistics.

\section{RESULTS}

The results of the biocompatibility in rat subcutaneous connective tissue were analyzed comparatively evaluating the experimental groups according to the periods of time.

In the 7-day period, the predominance of mild inflammatory infiltrate was observed in groups I (Figure 1) and III, and moderate infiltrate in groups II (Figure 2) and IV, and in group III (control), 100\% of the samples presented mild inflammatory reaction. Regarding the fibrous formation, Groups I, II and III presented fine collagen fibers and in Group IV, there was a complete absence of collagen fibers at $80 \%$. Abscess appeared in only $20 \%$ of Group II.

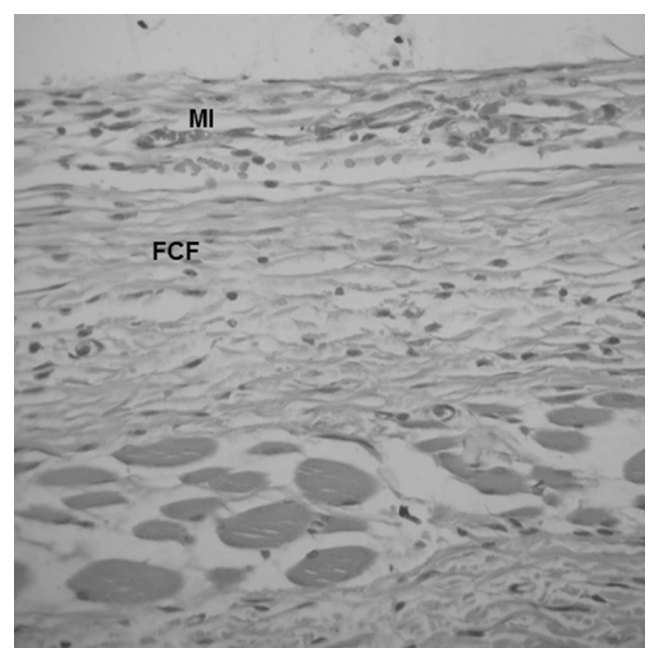

Figure 1. Group I (Propolis I) at 07 day - Mild inflammatory infiltrate (MI) and fine collagen fibers (FCF) 240x.

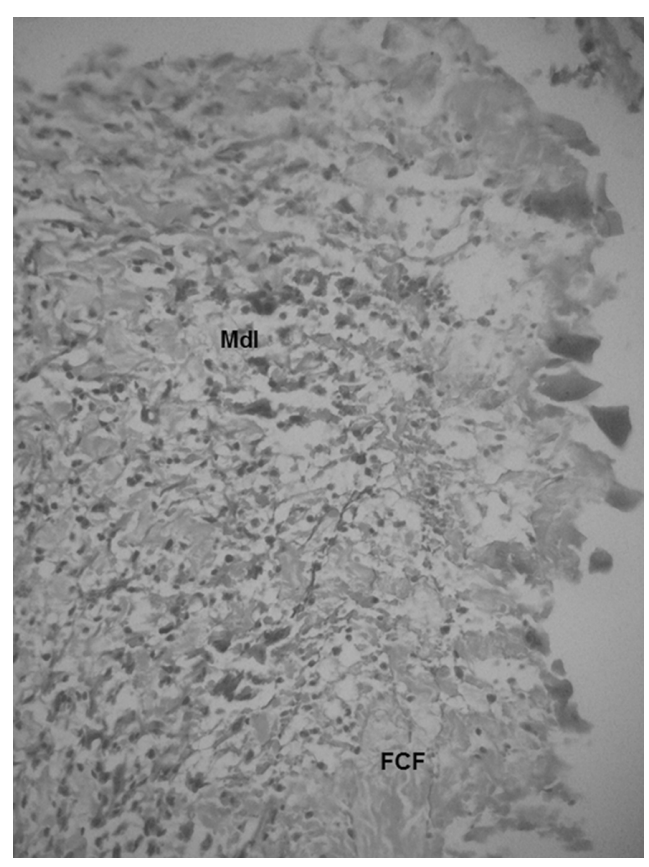

Figure 2. Group II (Propolis II) at 07 day - Moderate inflammatory infiltrate (Mdl) and fine collagen fibers (FCF) 240x. 
Analyzing the 30 and 45 day periods, it was observed that in 30 days, the absence of inflammatory infiltrate occurred for groups I and III, mild inflammatory infiltrate in Group II and the predominance of mild inflammatory infiltrate in Group IV. In 45 days, the predominance of absence of inflammatory infiltrate was observed in Groups I (Figure 3) and III (Figure 4), and predominance of mild inflammatory infiltrate in Group II (Figure 5), and in Group

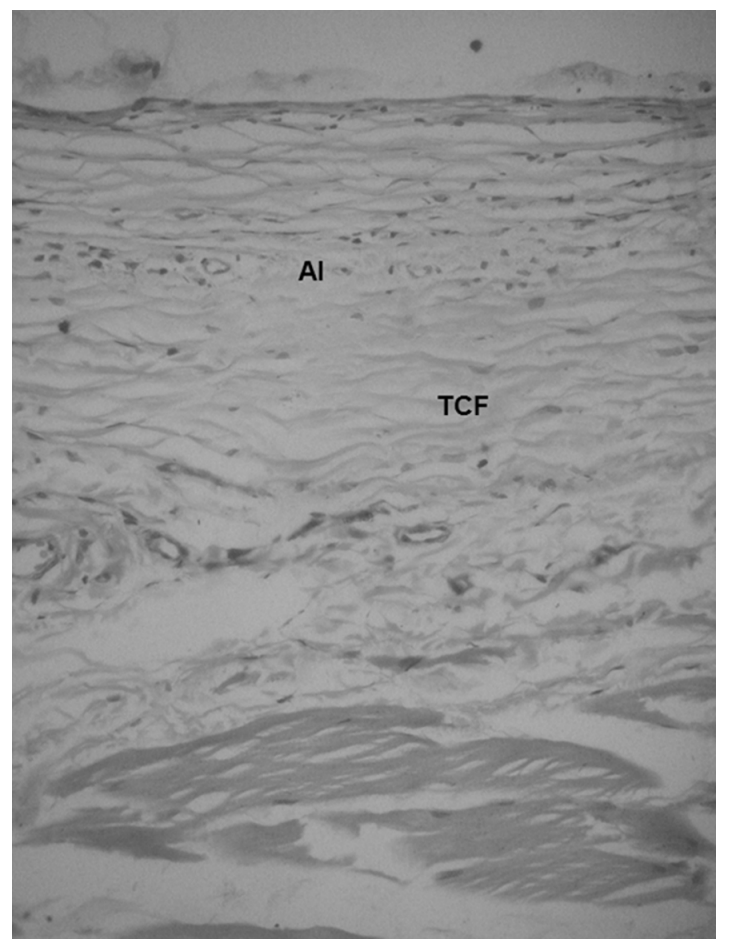

Figure 3. Group I (Propolis I) at 45 day - Absence inflammatory infiltrate (Al) and thick collagen fibers (TCF) 240x.

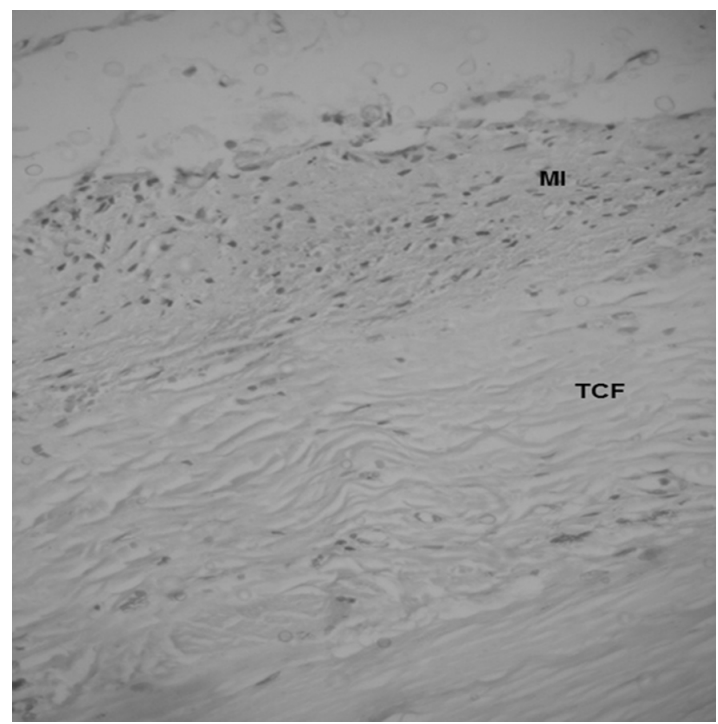

Figure 4. Group III (Chlorexidine) at 45 day - Mild inflammatory infiltrate (MI) and thick collagen fibers (TCF) 240x.
IV (Figure 6), 100\% of samples presented mild inflammatory reaction.

Overall, the inflammatory reaction regressed over the experimental periods and the collagen fibers grew thicker, with the Group III (control) presenting a more favorable inflammatory response followed by Groups IV, I and II. The CHW presented fine collagen fibers in all experimental periods.

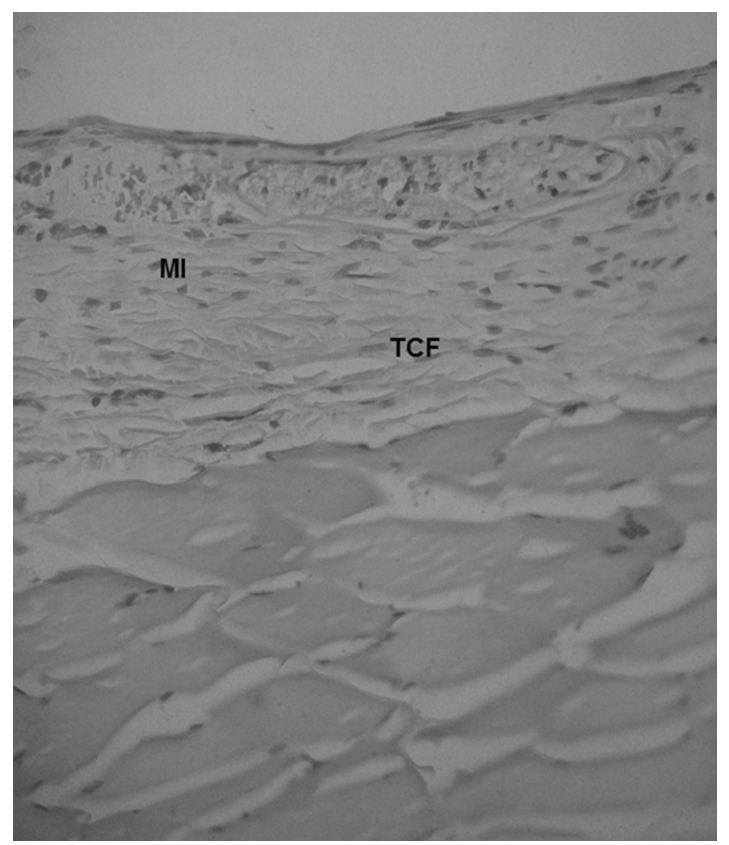

Figure 5. Group II (Propolis II) at 45 day - Mild inflammatory infiltrate (MI) and thick collagen fibers (TCF) 240x.

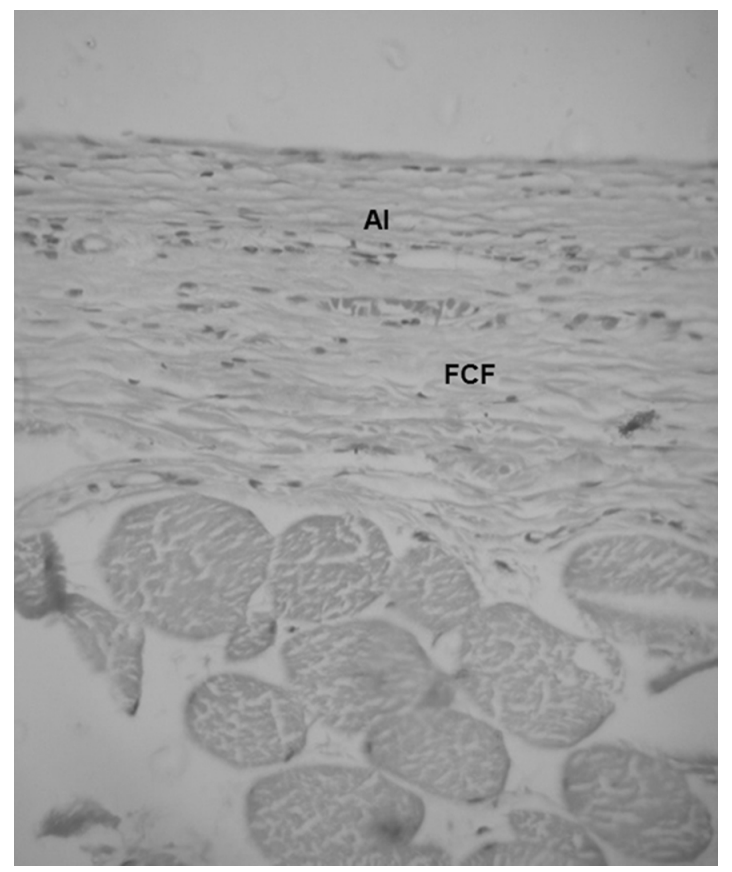

Figure 6. Group IV (Calcium Hydroxide-Water) at 45 day Absence inflammatory infiltrate (Al) and fine collagen fibers (FCF) 240x 
Comparing histopathologic analysis (inflammatory response, collagen fibers and abscess), the use of following materials can be suggested in decreasing order of biocompatibility: Group III - CHW, Group IV - CH, Group I - PI and Group II - PII.

The result of the toxicity test confirmed that $A$. franciscana was sensitive to $100 \%$ of the tested extracts, not only in relationship to PI, but also PII. It was observed that the tested extracts, based on the $A$. franciscana mortality rate, were classified in HT $(100 \%)$, showing its biologic property in the tested concentration.

The result of the hemolytic activity showed that in Group I (PI) there was no hemolysis in the extract concentrations starting from $0.01 \%$, and in Group II (PII) there was no hemolysis in the concentrations starting from $0.05 \%$.

\section{DISCUSSION}

When a new material is introduced into the market its properties should be investigated. From a biological standpoint, their biocompatibility must be evaluated, because the eventual toxic components present may cause tissue irritation, degeneration or necrosis of the tissues adjacent to the materials [13].

The research was a study that involved patent application delaying its disclosure, so it was used Artemia test, which is considered a preliminary study of low cost and easy handling on bioassay of extracts with strong biological activity [19], since the accomplishment of the lethality test allows the evaluation of the toxicity involving only one parameter: life or death [20].

This assay is simple, fast, practical and does not require aseptic technique and allows a large number of samples to be processed properly and these bioassays are useful for evaluating the exposure of a wide variety of extracts [21].

Silva et al. [22] affirmed that subsequently, another cytotoxicity test, such as the 3-(4,5-dimethylthiazol-2-yl)2,5-diphenyl-2H-tetrazolium bromide (MTT) assay, should be performed, since it is highly sensitive and has been indicated as a high-throughput screening assay.

The results comparing the inflammatory response of the tested materials on Day 7 show a more intense inflammatory infiltrate was found close to the tube opening in all groups and absence of collagen fibers. This may be due to responses to initial irritation in short periods when in touch with the tested material, or due to the surgical procedure [23]. Different results were observed by Nelson Filho et al. [24], who reported that calcium hydroxide induces less inflammatory infiltrate in the initial hours, progressing to a moderate degree after longer periods, and inducing subsequent tissue repair.

Garcia et al. [25] assessed the biocompatibility of two endodontic pastes based on calcium hydroxide and propolis, with two vehicles-non-fractionated Copaiba-oilresin (A) and volatile fraction of Copaiba-oilresin (B), in the connective tissue of rats, using the same methodology of this study. Tissue reaction ranged from slight (7/21 days) to no inflammation (42 days) for the control group, concluded that both pastes presented satisfactory tissue reaction in the connective tissue of rats, which is in accordance to the results found in this study, since the inflammatory reaction regressed over the experimental periods.

Analyzing the compatibility of dentinal adhesives Allbond $2^{\circledR}$ and Scotchbond MP ${ }^{\circledR}$, Costa et al. [26] observed that in the final periods, the histopathologic events regressed, showing a reparation process with intense presence of fibroblasts and collagen fibers, similar to this study.

Studies on biocompatibility of propolis are rare in the literature, and funding is lacking for comparing the results of this research. However, Geraldini et al. [27] suggested that because of propolis' antibacterial activity in the dentinal cavity, where there is a strict relationship between the dentin and the pulp, it can result in a favorable pulpal response, partially disagreeing with the histological findings of this study, where it was noticed that the proposed solution is similar to $\mathrm{CH}$, being indicated for shallow and medium cavities at $8 \%$ concentration.

About this, Bandeira et al. [3] evaluated the morphology of the dentin surface cut and treated with copaiba oil emulsions (CO) and suspension of ethanol extract of propolis (EP) through scanning electron microscopy (SEM), and the results suggest that copaiba oil emulsions (CO) and suspension of ethanol extract of propolis (EP) have feasibility to be used as bioactive dental cleaning agents.

New studies suggest the need for reducing the solution's concentration, aiming the analysis in deep cavities and in cavities with pulpal exposure in vivo.

\section{CONCLUSION}

The outcomes of the present study showed that in the biocompatibility test Propolis I and II were irritating to the rats subcutaneous connective tissue, enabling their application in shallow and medium cavities, similarly to $2 \%$ chlorhexidine and in the cytotoxicity test using $A$. franciscana the propolis extract presented high toxicity in the tested concentration and in the hemolytic activity test the Propolis I extract showed more activity than Propolis II. The inflammatory response of the calcium hydroxide solution reinforced its recommended use for cleaning deep cavities and cavities with pulpal exposure, being less toxic to tissues. Further research is necessary to determine the clinical behavior of propolis as a cavity cleaning in dentistry therapy.

\section{ACKNOWLEDGMENTS}

This research was funded by the Brazillian National Council for Scientific and Technological Development (CNPq) grant no 575752/2008-4 and registered at the National Institute of Industrial Property.

\section{REFERENCES}

1. Casagrande L, Seminario AT, Correa MB, Werle SB, Maltz M, Demarco FF Araujo FB. Longevity and associated risk factors in adhesive restorations of young permanent teeth after complete and selective caries removal: a retrospective study. Clin Oral Investig. 2017 Apr;21(3):847-855. https:// doi.org/10.1007/s00784-016-1832-1 
2. Rocha PI, Borges AB, Rodrigues JR, Arrais CAG, Giannini M. Effect of dentinal surface preparation on bond strength of self-etching adhesive systems. Braz Oral Res. 2006;20:52-58. https://doi.org/10.1590/S180683242006000100010

3. Bandeira MFCL, Lima GR, Lopes PP, Toda C, Venâncio GN, Lima GA, Vasconcellos MC, Martins LM, Sampaio FC, Conde NCO. Dentin cleaning ability of an Amazon bioactive: evaluation by scanning electron microscopy. Open Dent J. 2016 (Suppl 1, M5):182-187. https://doi. org/10.2174/1874210601610010182

4. Bankova V. Recent trends and important developments in propolis research. Evid Based Complement Alternat Med. 2005 Mar;2(1):29-32. https://doi.org/10.1093/ecam/neh059

5. Salomão K, Pereira PR, Campos LC, Borba CM, Carbello PH, Marcucci $\mathrm{MC}, \mathrm{DE}$ Castro SL. Brazilian propolis: correlation between chemical composition and antimicrobial. Evid Based Complement Alternat Med. 2008 Sept;5(3):317-324. https://doi.org/10.1093/ecam/nem058

6. Teixeira EW, Message D, Negri G, Salatino A, Stringheta PC Seasonal variation, chemical composition and antioxidant activity of Brazilian propolis samples. Evid Based Complement Alternat Med. 2010 Sept;7(3):307-315. https://doi.org/10.1093/ecam/nem177

7. Ota C, Unterkircher C, Fantinado V, Shimizu MT. Antifungal activity of propolis on different species of Candida. Mycoses. 2001 Nov;44 (9-10):375-378. https://doi.org/10.1046/j.1439-0507.2001.00671.x

8. Lotufo MA Shimizu MT, Cabral R, Birman EG. Clinical evaluation of the topical use of propolis in recurrent minor aphthous ulceration. Cienc Odontol Bras.2005 July-Sept;8(3):6-9

9. Carballo DD, Malak S, Bardenheuer W, Freistuehler M, Peter R H. The contribution of plukenetione $A$ to the anti-tumoral activity of Cuban propolis. Bioorg Med Chem. 2008 Nov;16(22):9635-9643. https://doi. org/10.1016/j.bmc.2008.10.019

10. Sardana D, InduShekar KR, Manchanda S, Saraf BG, Sheoran N. Role of propolis in dentistry: review of the literature. Focus Alternat Complement Ther. 2013 Sept;18(3):118-125. https://doi.org/10.1111/fct.12034

11. Groppo FC, Bergamaschi CC, Cogo K, Franz-Montan M, Motta $\mathrm{RHL}$, Andrade ED. Use of phytotherapy in dentistry. Phytother Res 2008;22(8):993-998. https://doi.org/10.1002/ptr.2471

12. Palombo EA. Traditional medicinal plant extracts and natural products with activity against oral bacteria: potential application in the prevention and treatment of oral diseases. Evid Based Complement Alternat Med. 2011;7:1-15. https://doi.org/10.1093/ecam/nep067

13. Park YK, Ikegaki M. Preparation of water and ethanolic extracts of propolis and evaluation of the preparations. Biosc Biotechnol Biochem. 1998 Aug;62(11):2230-2232. https://doi.org/10.1271/bbb.62.2230

14. Bauer J, Al-rubayi A. Tissue response to direct filling materials. J Prosthet Dent. 1987 Nov;58(5):584-589. https://doi.org/10.1016/00223913(87)90388-X

15. Figueiredo JAP, Pesce HF, Gioso MA, Figueiredo MAS. The histological effects of four endodontic sealers implanted in the oral mucosa: submucous injection versus implant in polyethylene tubes, Int Endod J 2001 Dec;34(5):377-385. https://doi.org/10.1046/j.1365-2591.2001.00407.x

16. Meyer BN, Ferrigini NR, Putnam JE, Jacobsen LB, Nichols DE, McLaughlin JL. Brine shrimp: a convenient general bioassay for active plant constituents. Planta Med. 1982 May;45(5):31-34. https://doi. org/10.1055/s-2007-971236

17. González AM, Presa M, Latorre MG, Lurá MC. Detection of fungal metabolites showing toxic activity though Artemia salina bioassay. Rev Iberoam Micol. 2007;24(1):59-61. https://doi.org/10.1016/S11301406(07)70015-3

18. Kitagawa S; Sakamoto $\mathrm{H}$; Tano $\mathrm{H}$. Inhibitory effects of flavonoids on free radical- induced hemolysis and their oxidative effects on hemoglobin. Chem Pharm. Bull. 2004 Aug;52(8):999-1001. https://doi.org/10.1248/ cpb.52.999

19. Stefanello MEA, Salvador MJ, Ito MY, Macari PAT. Avaliação da atividade antimicrobiana e citotóxica de extratos de Gochnatia polymorpha ssp floccosa. Rev Bras Farmacogn. 2006;16(4):525-530. https://doi. org/10.1590/S0102-695X2006000400015

20. Cavalcante MF, de Oliveira MCC, Velandia JR, Echevarria A. Síntese de 1,3,5-triazinas substituídas e avaliação da toxicidade frente a Artemia salina Leach. Quím. Nova, São Paulo. 2000;23(1):20-22.

21. Rice SA, Maness IB. Brine Shrimp bioensays a useful technique in biological investigations. Am Biol Teach. 2004;66(3):208-214. https://doi org/10.2307/4451655

22. Silva EMF, Nascimento RBC, Barreto FS, de Moraes Filho MO, Griz SAS, dos Santos AF, Mousinho KC. Estudo in vitro do potencial citotóxico da Annona muricata L. Rev Ciênc Farm Básica Apl. 2015;36(2):277-283.

23. Mastrantonio SS, Ramalho LTO. Mouse connective tissue reaction to poliurethane derived from castor oil. Rev Odontol UNESP. São Carlos. 2003;32(1):31-37

24. Nelson Filho P, Silva LA, Leonardo MR, Utrilla LS, Figueiredo F. Connective tissue responses to calcium hydroxide-based root canal medicaments. Int Endod J. 1999 Aug;32(4):303-311. https://doi.org/10.1046/j.13652591.1999.00225.x

25. Garcia L, Santos C, Mestrine Jr. W, Mestrine Jr. S, Lopes RA, Ramos M, Freitas $\mathrm{O}$. Biocompatibility assessment of pastes containing Copaiba oilresin, propolis, and calcium hydroxide in the subcutaneous tissue of rats. J Conserv Dent. 2011 Apr-June;14(2):108-112. https://doi. org/10.4103/0972-0707.82601

26. Costa CA, Teixeira HM, Nascimento AB, Hebling J. Biocompatibility of two current adhesive resins. J Endod. 2000 Sept;26(9):512-516. https://doi. org/10.1097/00004770-200009000-00006

27. Geraldini CAC, Salgado EGC, Rode SM. Ação de diferentes soluções de própolis na superfície dentinária - avaliação ultra-estrutural. Rev Fac Odontol. São José dos Campos. 2000 July-Dec;3(2):37-42. 